Revue Française de Civilisation Britannique

\title{
What Does It Mean to Be Leader of a "One Nation Conservative Government"? The Case of Boris Johnson
}

Que signifie être le leader d'un gouvernement conservateur 'one nation'? Le cas

de Boris Johnson

\section{Raphaele Espiet Kilty}

\section{(2) OpenEdition}

\section{Journals}

Electronic version

URL: http://journals.openedition.org/rfcb/5862

DOI: $10.4000 /$ rfcb.5862

ISSN: 2429-4373

\section{Publisher}

CRECIB - Centre de recherche et d'études en civilisation britannique

\section{Electronic reference}

Raphaele Espiet Kilty, "What Does It Mean to Be Leader of a "One Nation Conservative Government"? The Case of Boris Johnson », Revue Française de Civilisation Britannique [Online], XXV-3 | 2020, Online since 10 September 2020, connection on 10 September 2020. URL : http://journals.openedition.org/ rfcb/5862 ; DOI : https://doi.org/10.4000/rfcb.5862

This text was automatically generated on 10 September 2020.

\section{c) () $($ )}

Revue française de civilisation britannique est mis à disposition selon les termes de la licence Creative Commons Attribution - Pas d'Utilisation Commerciale - Pas de Modification 4.0 International. 


\section{What Does It Mean to Be Leader of a "One Nation Conservative Government"? The Case of Boris Johnson}

Que signifie être le leader d'un gouvernement conservateur 'one nation'? Le cas de Boris Johnson

Raphaele Espiet Kilty

\section{Introduction}

1 In May 2019, a new Tory group, the One Nation Caucus², spearheaded by Cabinet Minister ${ }^{3}$ Amber Rudd, was formed in a bid to block candidates who backed no-deal Brexit in the leadership contest due to start upon Theresa May's resignation as Prime Minister. On 20 May, the group issued a manifesto that took aim at Boris Johnson, the most likely winner of the leadership contest. In spite of the group's support for the proEuropean Jeremy Hunt, he was defeated by Johnson on 24 July 2019. On 7 September 2019, Rudd quit Johnson's government, with an outspoken attack on the PM's approach to Brexit. A few months later, the PM finally got his wish for a general election to be held in December which he duly won. On 13 December 2019, in Downing Street, Prime Minister Johnson announced the formation of what he called a "new One Nation Conservative Government, a people's government" 4 . This dramatic succession of events not only tells the story of Brexit since that fateful day in June 2016, it also raises questions as to what One Nation Conservatism is, if two supposedly opposed factions within the same party can both claim to be One Nation.

2 The prefix itself is far from being a new one. Attributed to Conservative leader and Prime Minister Benjamin Disraeli, it was first coined by Stanley Baldwin in the 1930s and then became theorised in 1950 with the publication of One Nation, a pamphlet 
drafted by several leading Conservatives. The group seemed to dominate the debate of ideas until Margaret Thatcher, on becoming leader of the Conservative Party in 1975, immediately set about breaking from the so-called socio-economic consensus of the 1945-75 period, thus presenting herself as One Nation Conservatism's ideological opponent. The period of her premiership, from 1979 to 1990, was characterised by an ever-increasing influence of Thatcherite Think Tanks and political groups whose hold on the party extended into the new Millennium. In October 2002 the still relatively unknown Chairman of the Conservative Party, Theresa May, made a speech to the Conservative Party Conference in Bournemouth which heralded the ascent of the modernist and self-proclaimed compassionate faction of the party that would, in 2005, be spearheaded by David Cameron. "Our base," she argued "is too narrow and so, occasionally, are our sympathies," concluding that "some people call us - the nasty party." To reverse this trend, the party had to commit to change in order to represent "the whole of Britain", one nation. Cameron's Big Society programme was to be the means by which "a society which cares for vulnerable people" would be revived and the agent of this social renewal was to be civil society. One Nation Conservatism was reborn, at least on the face of it. A decade on, the Coalition Government, of which both Theresa May and Boris Johnson were prominent members, had arguably failed to deliver the Big Society and, therefore, most of its One Nation agenda. Then, Brexit sealed the Prime Minister's fate and triggered a contest between Conservative MPs for the leadership of the party and the government. In her campaign, May pledged to be the candidate of "the ordinary, working people," arguing that she embodied "a different kind of Conservatism." Was Theresa May not a One Nation Conservative like Cameron had claimed to be? That would be the obvious presumption, and an issue that needs to be addressed. Three years later, it was her turn to tumble over the Brexit issue and give way to Johnson, her former Foreign Secretary, as he became the new leader of the party. In a move that many thought was a gamble, the new Prime Minister decided to call an election to be held on 12th December. In the Conservative and Unionist Party Manifesto 2019, Johnson stated that there were "parts of the country that feel left behind," because opportunity was not "uniformly distributed throughout the country." The remedy he proposed was "to close that gap - not just because it makes such obvious economic sense, but for the sake of simple social justice," describing his future government as the "new One Nation Conservative Government", one that would be One Nation on account of giving "the NHS its biggest ever cash boost."

3 This paper argues that given the flexible, changing and pragmatic nature of One Nation Conservatism, it might be possible to accept Johnson's proposition that his government could be a One Nation Conservative Government, at least on the face of it. However, in so far as Johnson's programme seems to be lacking any clear ideological and intellectual underpinnings, we will contend that his One Nation probably amounts more to a rhetorical discourse with little underlying substance the aim of which was to capture the blue-collar support for the 2019 election. However, cannot One Nation Conservatism also be just that?

4 The approach will be a historical one with, in the first part, a presentation of One Nation Conservatism from its birth onwards that will enable us, in the second part, to assess whether it is possible to position Johnson in this intellectual tradition. The second part will further examine Johnson's One Nation Conservatism in relation to his two direct predecessors'. The third part will consider the more loaded charge that One Nation "in a way has just become a code term for trying to make the party electable and to keep 
the party electable," 5 to quote Lord Biffen, himself a leading One Nation Conservative. If this is so, then it could be possible to argue that Boris Johnson is indeed part of this opportunistic One Nation Conservative tradition.

\section{The One Nation tradition: from Disraeli to Cameron}

5 In his Manchester and Crystal Palace Speeches of April and June 1872, Benjamin Disraeli, then leader of Her Majesty's Opposition to William Gladstone's Liberal Government, outlined his programme to unite the Conservative Party for the upcoming general election. He declared:

Gentlemen, The Tory Party, unless it is a national party, is nothing. It is not a confederacy of nobles, it is not a democratic multitude; it is a party formed of all the numerous classes in the realm - classes alike and equal before the law, but whose different conditions and different aims gives vigour and variety to our national life. ${ }^{6}$

6 He thus gave form to a thesis that he had developed twenty-seven years earlier in his famous novel sybil, or The Two Nations. If the Tory Party wanted to carry on winning elections, they had to adapt to represent the "numerous classes" forming British society, in fact: the Two nations. Disraeli never used the expression One Nation either alone or indeed in association with Tory party and Tim Bale even claims that he did not have " much practical involvement in some of the $19^{\text {th }}$ century social and industrial reforms retrospectively associated with it"7. It must be noted indeed that recent historiography is not so kind to Disraeli. Robert Walsha argues that "he was not the progressive visionary most used to say he was" ${ }^{\text {. }}$. Whether one can speak about a Disraelian myth or not, there remains the fact that the twentieth century One Nation Conservatives built on the fame, maybe even the cult, of their great predecessor and the moral of the story of young Sybil that bridging the gap between the two nations, i.e. the rich and the poor, (by, amongst other things, appealing to the feeling of Noblesse Oblige of the rich) was a necessary condition to bringing about social peace and social harmony.

7 The first twentieth century Conservative to exploit the myth of the Conservative Party being One Nation, some even argue it was actually he who coined the expression for the first time, was Stanley Baldwin. He justified sweeping government intervention in the name of One Nation, arguing that the Conservative Party had to abandon its laissez faire stance to tackle the economic crisis caused by the 1929 crash. However, Walsha again argues that, like Disraeli before him, Baldwin failed to match rhetoric with action'. Then the war broke out followed by six years of Labour rule with the Prime Minister, Clement Attlee, establishing the British Welfare State, thus radically transforming Britain's social landscape. The trauma of the great crisis so shortly preceding a war was discernible in most of the economic and social policies established by both the Labour and Conservative upcoming governments. This is best epitomised by the Beveridge Report on the one hand and the following assertion by Conservative Quentin Hogg (Lord Hailsham) who takes up expressions used in the aforementioned report on the other:

This twentieth century society demands a measure of control to prevent chaos. The price of ignoring this need is unemployment, cut-throat competition, unbalanced economy, unjust distribution of wealth, slums, ignorance, bitterness, squalor and in the end [class] war. ${ }^{10}$ 

outcome of which was the birth of the intellectualised or theorised One Nation tradition with the publication of the One Nation pamphlet in 1950. For the first time, One Nation was no longer just part of the realm of public/oral discourse. It actually became a written set of beliefs and a programme for the future. The idea was to help form an enabling state with a One Nation vision that would be what Peter Dorey and Mark Garnett call a "middle way between the extremes of Manchester"11 and Moscow"12. The responsibility of promoting social harmony would befall on a state that, according to the One Nation authors of the pamphlet would not abandon its sound economic vision, based on the belief in free trade and relatively low personal and corporate taxes, but would still favour the industrial policies that specifically showed that the Conservatives were human ${ }^{13}$, rather than being completely detached from the majority of the population. The original, and only the most famous, founders of the One Nation Group were Iain Macleod, Enoch Powell, Edward Heath, Robert Carr and Angus Maude, later joined by the likes of Keith Joseph ${ }^{14}$ for example. They all had diverse if not divergent views on both social and economic issues as Powel and Joseph's trajectories would later demonstrate. They disagreed on how much the government could intervene to provide social harmony through the establishment of a bureaucracy responsible for the management of welfare. They disagreed on how far the government could go to guarantee economic welfare through full employment. And they disagreed on how much the government could tax citizens in order to be able to foot the bill of both the aforementioned policies. But they all shared the same idea that the Conservative Party needed to have a pragmatic approach to social changes in order to appeal to a wider electorate.

these disagreements as well as agreements are discernible in the succession of pamphlets and booklets the Group has published since 1950. For example, it is noticeable that within the space of only four years between the initial one Nation pamphlet of 1950 and Change is Our Ally published in 1954, the group had already evolved on economic matters and adopted a much more free market position, much more here definitely implying that it was already extant in the original pamphlet. David Seawright contends that Change is Our Ally announced the neoliberal shift. And indeed, although Margaret Thatcher is often regarded as opposed to One Nation Conservatism, which she really was in many ways - after all, she was to set herself as their ideological opponent -, she still provided a foreword to One Nation Group: One Nation at Work published in 1976. She also regarded her home-ownership programme as truly Disraelian One Nation ${ }^{15}$. Noticeable also is the fact that the group has rarely had a totally different agenda from that of the Party in office except maybe at the time of the Thatcher governments, as we have already argued ${ }^{16}$. And even so, Dorey, Garnett and Walsha contend that the reason why this was the case was because many disaffected Conservative members ${ }^{17}$, either dismissed from the government or who had had problems with the Prime Minister, trumpeted their One Nation credentials which they used to voice their discontent. Some of them had not been members of the group before. Edward Heath, however, had been a member of the group since 1950 and his influence was still perceptible. His opposition to most of Margaret Thatcher's policies was undeniable. One Nation then became of way of distancing the Conservative Party from the increasingly dogmatic and inflexible approach and style of the Prime Minister. This was a battle that, although Thatcher was made to resign in 1990, the One 
Nation Conservatives would ultimately lose given the pervasiveness of Thatcherism within the party.

By the time Tony Blair became PM in 1997, the One Nation group no longer led the intellectual debate within the party. Thatcher's vision had changed the party and the new generations of Conservatives were often more Thatcherite, more pro-free market and more anti-Europe than she herself had ever been. Dorey and Garnett in particular, stress that there was a generational shift within the party as most of the new members had experienced neither the Great Depression nor the Second World War. They contend that there was what they call "a change of ethos"18. In many ways in fact, Margaret Thatcher was the first of this new generation of Conservatives who had no first-hand experience of either the Great War or the 1930's crash (she was born in 1926). Tim Bale suggests that the proportion of members of Conservative MPs committed to free market economics had risen from $56 \%$ in 1992 to $73 \%$ in 2001, while Eurosceptics made up $90 \%$ of the parliamentary party ${ }^{19}$. The result was that over most of the period of New labour, the One Nation group was at once far less dominant than before and much more right-wing than one would expect from a group that had the reputation of being quite progressive or, to quote Walsha "unequivocally on the party left" ${ }^{20}$. William Hague who became leader of the Conservative Party in 1997, is one of the examples of this shift. He was 36 years old, a 'true blue', rather Eurosceptic Conservative and also a member of One Nation Group (1993). An altogether very different One Nation Conservative from Edward Heath. To complete this picture, Thatcher had been instrumental in ensuring Hague's victory as John Major's successor, regularly posing beside him in photographs or making an appearance during his speeches. His successor, Iain Duncan Smith, was a member of the very Thatcherite No Turning Back Group, which seemed to have more influence within the party in spite of the increasingly obvious fact that the Thatcher legacy had become toxic, playing an important part in keeping the party on the wrong side of the House of Commons.

11 It was Theresa May, not herself a member of any group, who provided the rhetorical turning point with her "nasty party" comment in $2002^{21}$ :

There's a lot we need to do in this party of ours. Our base is too narrow and so, occasionally, are our sympathies. You know what some people call us - the nasty party.

I know that's unfair. You know that's unfair but it's the people out there we need to convince - and we can only do that by avoiding behaviour and attitudes that play into the hands of our opponents. No more glib moralising, no more hypocritical finger-wagging.

We need to reach out to all areas of our society.

I want us to be the party that represents the whole of Britain and not merely some mythical place called "Middle England", but the truth is that as our country has become more diverse, our party has remained the same.

David Cameron became a member of the One Nation Group a few months later (2003) and within another few months had established himself as the leader of the progressive faction within the party. His victory in the leadership of the Conservative Party contest in 2005 was a setback for the No Turning Back Group but was it a victory for One Nation Conservatism?

13 In spite of the strong association often made between Cameron and One Nation Conservatism, he himself only used the label after his victory at the 2015 general election (the manifesto does not mention One Nation Conservatism). Before then, he 
had willingly described himself as a progressive Conservative ${ }^{22}$ or a Liberal one ${ }^{23}$, and his Conservatism as modern and compassionate ${ }^{24}$. One of the possible explanations might be that party activists were wary of the label. Was it too early for most Tories who were still reluctant to let go of the Thatcher legacy? ${ }^{25}$. When Cameron finally declared: "we will govern as a party of one nation", on the doorstep of 10 Downing Street the one nation was "the United Kingdom (...) from north to south, from east to west" and, according to the manifesto, the "Northern powerhouse" mentioned immediately afterwards was Scotland ${ }^{26}$. The association between Cameron and One Nation therefore entirely rested on his repeated use of the adjective compassionate to describe his Conservatism and therefore on people's presumption that compassionate meant One Nation.

When Theresa May became leader, she paid rare lip service to the term, preferring to distance herself from Cameron and therefore using another terminology. To a certain extent, at least on the face of it, one Nation Conservatism was really revived by the One Nation Caucus that was formed in May 2019, to block candidates who backed no-deal Brexit, Johnson included. Paradoxically Johnson, first in his manifesto and then in his first speech on becoming PM in December 2019 also claimed to be a One Nation Conservative. The question is, were any of these three recent appeals to One Nation Conservatism more than just rhetorical exercices?

\section{One Nation and society from Cameron to Johnson}

We have already seen that on economic issues at least, a more accurate suggestion is probably that the One Nation group has always been divided. Better contend that overall, they have more or less followed the same trend as liberalism itself, from classic to social and then to neo. Because of this, their position regarding the role of the state has also varied over time from considering the state as a positive force for good, an agent of both economic and social progress (Baldwin, Butler, 1950 Pamphlet, etc.) to viewing it as part of the problem (Thatcher, Cameron, Johnson). In many ways, Cameron was nearly the perfect illustration of these tensions. He declared himself to be progressive, spoke about social justice and the need to be compassionate, did not hesitate to address the often fraught issue of poverty, fraught for the Conservative Party, whilst at the same time arguing that the state, in fact too much state, could never be the solution:

For labour there is only the state and the individual, nothing in between. No family to rely on, no friend to depend on, no community to call on. No neighbourhood to grow in, no faith to share in, no charities to work in. No-one but the Minister, nowhere but Whitehall, no such thing as society - just them and their laws, and their rules, and their arrogance - you cannot run our country like this. ${ }^{27}$

And indeed, on becoming leader of the Conservative Party in 2005, Cameron declared: " There is such a thing as society, it's just not the same thing as the state." ${ }^{28}$ The result was a synthesis between the market as the driver of economic growth/policies and society in fact the Big Society - to repair so-called "Broken Britain" ${ }^{29}$. His was very much a civic Conservatism, a form of Conservatism not at all unknown to the party. To a certain extent, this civic Conservatism that sought to promote social harmony through policies aimed at encouraging, fostering, supporting, helping civil society repair society rather 
than top-down central government policies was what Conservatism had very often been about (even under Thatcher) with or without the One Nation prefix.

Cameron's flagship social programme, i.e. the Big Society, was the means by which he asserted his One nation credentials, the Big Society being one nation in which everyone, regardless of their social background, should contribute to the wellbeing of all by facing up to their responsibilities to others, to society as well as indeed to themselves. The Big Society was the belief that it was only through collective action that poverty would be curbed and citizenship of this society was defined by the obligations of all rather than the rights of all.

The problem with Cameron's compassionate Conservatism was not so much that it was only rhetorical as that it was, in spite of the rhetoric, not the priority in practice. The priority was economic austerity, resulting in cuts to public spending, which caused a significant reduction in investments in social services by local authorities. All in all, the Coalition Government's austerity damaged the very civil society that they were seeking to encourage. Unsurprisingly? The paradoxical nature of Cameron's compassionate Conservatism is maybe best expressed in the knowledge that most of the Coalition Government's social policies were enforced by the Thatcherite Iain Duncan Smith (IDS) who, as Cameron's Secretary for Work and Pensions from 2010 to $2015^{30}$, was responsible for the rolling out of Universal Credit which caused an increase in both absolute and relative poverty ${ }^{31}$. It was also IDS who, as founder ${ }^{32}$ and chairman ${ }^{33}$ of the Centre for Social Justice - the name is itself a paradox coming from a Thatcherite - had contributed to the shaping of most of Cameron's social message, as well as his "Broken Britain" analogy ${ }^{34}$.

19 Cameron's sudden use of the One Nation prefix in 2015, to replace the "modern" and "compassionate" adjectives of the 2005 and 2010 campaigns was evidence that the Conservative Party was aware that the Coalition Government's policies had endangered the social cohesion that Cameron had said he would restore. And this was indeed the accusation levelled at Cameron by his former Home Secretary when she campaigned for the leadership of the Conservative Party in July 2016.

Theresa May, unlike Cameron, was not a member of the One Nation Group and she only paid lip service to the tradition, never really acknowledging it as her own. Rhetorically, the main difference between May and Cameron was her belief in the role of the state as a positive agent for good, in her case at the service of "the ordinary, working people," to make Britain "a country that works for everyone" 35 . May promised a return to a more traditional Conservatism. "This," she said at the launch of her leadership campaign, "is a different type of Conservatism. (...). It makes a break with the past. But it is in fact completely consistent with Conservative principles" ${ }^{36}$. The principles mentioned here are those of the pre-Thatcher era when Conservatives did not deny a positive role for the government, when it is argued that the party was, in fact, more One Nation. She also declared: “(...) we don't just believe in markets, but in communities. We don't believe in individualism, but in society" ${ }^{37}$, but a society that, unlike Cameron's, was not different from the state ${ }^{38}$. And indeed, May did not seem to have the perception that the state was "the enemy" 39 . Her main declaration was that she would govern from the mainstream: "Rather than pursue an agenda based on a supposed centre ground defined and established by elites in Westminster, we will govern in the interest of the mainstream of the British public" ${ }^{40}$. The target was not only David Cameron but also his so-called "Notting Hill set" of millionaire cabinet members who professed to incarnate a compassionate Conservatism but then "allowed" 
the agenda "to drift to the right" to serve the interests of the rich and powerful. The attack was clearly levelled at Cameron's One Nation Conservatism, which she condemned as a simple façade. However, in calling out Cameron's hypocrisy, was she declaring herself a truer One nation Conservative? To a certain extent, at least on the face of it, the answer is a cautious yes. Her many declarations positioned her much closer to the traditional One Nation Conservatism than she herself acknowledged. A Conservatism that saw a role for the government in achieving social harmony by intervening to alleviate some of the most blatant inequalities caused by unfettered capitalism and the belief in free markets. Whatever her instincts, however, Theresa May fell short of achieving what she ${ }^{41}$ believed in..$^{42}$ In effect, her social programme did not promise much in the form of social progress and government involvement to make Britain "a country that works for everyone." Her policies were indeed devoid of any significant thrust to re-build one nation by bridging the gap between the rich and the poor.

21 However, at this juncture, it is necessary to specify that One Nation Conservatism or indeed Conservatism without any prefix is not about one nation of equal individuals. And this is an important aspect that needs to be mentioned for fear of mistaking One Nation Conservatism. From Disraeli to Johnson, Conservatives have never believed in equality between individuals and, albeit more recently, do not support redistributive policies the aim of which would be to spur on the development of a more socially egalitarian society that, so they contend, deprive society and individuals of their freedom. In 1835, Disraeli explained: "The basis of English society is Equality. But here let us distinguish: there are two kinds of equality; there is the equality that levels and destroys, and the equality that elevates and creates..."43. In 1975, Margaret Thatcher declared: "We are all unequal. No one, thank heavens, is like anyone else, however much the Socialists may pretend otherwise." ${ }^{44}$ When pressed on the matter, they would rather argue that they believe in freedom and equality of opportunities. In 2010, Theresa May stated:

But even as we increase equality of opportunity, some people will always do better than others. And, certainly, I do not believe in a world where everybody gets the same out of life, regardless of what they put in. That is why no government should try to ensure equal outcomes for everyone. ${ }^{45}$

Boris Johnson in his own, rather crude, words, epitomised the Conservative definition of equality. Giving the annual Centre for Policy Studies Margaret Thatcher lecture in London in 2013, the then Mayor of London argued that economic equality was not possible because natural differences between human beings meant that some people would always find it easier to get ahead than others adding: "Whatever you may think of the value of IQ tests, it is surely relevant to a conversation about equality that as many as 16 per cent of our species have an IQ below 85, while about 2 per cent have an IQ above 130." $\mathrm{He}$ further developed this idea explaining : I don't believe that economic equality is possible; indeed, some measure of inequality is essential for the spirit of envy and keeping up with the Joneses and so on that it is a valuable spur to economic activity," ${ }^{46}$ finally asserting that free markets involved competition between "human beings who are far from equal in raw ability ". In his own style, Johnson simply summarised what most Conservatives believed, including One Nation Conservatives, that, in spite of Disraeli's Sybil, making the rich poorer in order to make the poor richer cannot be the objective all the more so as poverty is inevitable given the differences between individuals. The objective is equal opportunities before the law. There are, however, gradations in the levels of inequality 
that can be such that they can cause social unrest. One of the differences between One Nation Conservatives and the more right-wing ones is the belief that to preserve social harmony is an important role for the government, if not always as important as to guarantee economic growth. Hence the assumption that One Nation Conservatism has a more compassionate approach to social issues than, obviously, the more right-wing Conservatism of Margaret Thatcher, for example. It explains the choice of this adjective by Cameron and why there was an immediate association between compassionate and One Nation, although Cameron only used the prefix One Nation in 2015. Cameron's One Nation compassionate Conservatism may have been a smokescreen to hide less than compassionate social policies but the rhetoric, at least, was congruent with the One Nation tradition of fostering social harmony by calling upon the "little platoons" to increase their role, and it positioned Cameron to the more liberal left of the party. By adopting the more divisive rhetoric of the Thatcher era, insisting that inequality was an engine of economic growth and by campaigning for Brexit, Johnson raised serious doubts as to his belonging to the One nation tradition. It raised equally serious questions as to whether his self-fashioned One Nation Conservatism was not just part of a contingency plan to win the 2019 election and cut the grass from under the One Nation Caucus' feet.

\section{One Nation Conservatism: an opportunist approach to winning elections?}

In his first speech as PM, Johnson pledged more police, shorter waits for GPs, hospital upgrades and more money into the NHS, to fix the crisis in social care, superb education, all this for the whole of the UK. And indeed, he promised to be the Prime Minister of the whole of the UK, by "physically and literally renewing the ties that bind us together so that with safer streets and better education and fantastic new road and rail infrastructure and full fibre broadband, we level up across Britain." ${ }^{{ }^{77}} \mathrm{He}$ completed his speech arguing: "it is free trade that has done more than anything else to lift billions out of poverty." ${ }^{48}$ Unless Johnson's One Nation Conservatism is yet another version of the brand, there is not much that is truly congruent with the One nation tradition in his speeches unless One Nation simply means for the whole of the nation.

Unlike Cameron and most of the members of the One Nation Caucus formed partially against him (Damian Green, Oliver Letwin, Francis Maude, etc.), Johnson was never a member of the One Nation Group and his first declarations before December 2019 certainly suggest that he was much closer to Thatcherism than to One Nation Conservatism. And indeed, in his 2019 Conservative Party Conference speech, he did not hesitate to take up Thatcher's terminology, talking about "symmetry at the heart of the modern British economy between a dynamic enterprise culture and great public services." ${ }^{9}$ And yet, as early as April 2010, he was already explaining to the Telegraph:

I'm a one-nation Tory. There is a duty on the part of the rich to the poor and to the needy, but you are not going to help people express that duty and satisfy it if you punish them fiscally so viciously that they leave this city and this country. I want London to be a competitive, dynamic place to come to work. ${ }^{50}$ that he asserted again on the doorstep of 10 Downing Street, immediately after the party's historic victory at the December 2019 general election. Paul Goodman, editor of 
the centre-right political blog ConservativeHome, rather ironically defined Johnson's One Nation label in front of Conservatism as: " $a$ way of describing his midlands-northern focus, infrastructure-friendly, pro-NHS, migration-suspicious, tough on crime and interventionist 'boosterism"'51. Admittedly, there is not much in Johnson's programme that truly rings One Nation apart from his pledge to support the NHS (Johnson's only social pledge $)^{52}$ :

One Nation Conservative Government is giving the NHS its biggest ever cash boost, with 20 hospital upgrades and 40 new hospitals, while delivering 50,000 more nurses and 6,000 more doctors and creating an extra 50 million general practice appointments a year. ${ }^{53}$

His One Nation pledge also rests on the HS2 (High Speed 2) project inherited from David Cameron and aimed at connecting London to Birmingham and then Manchester and Leeds. The project was approved by Johnson in February 2020 after the publication of the Oakervee Review ${ }^{54}$. This is to allow everyone in Britain, One Nation, to have access to the same business opportunities and therefore wealth:

If this Conservative Government is returned to office, we will have an infrastructure revolution for this country. Now is the time to invest in Northern Powerhouse Rail, and the Midlands Rail Hub, and so many more projects, as well as a massive programme of improvements for our roads and gigabit broadband for every home and business. ${ }^{55}$

In this case, One Nation for Johnson is to be taken more literally as one physical nation rather than a social one. Although in this particular instance one nation is only England, there is a case for mentioning One Nation in the wider context of the whole of the United Kingdom. Obviously, the UK is four nations as one and to insist on preserving the Union is indeed a very important aspect of Conservatism. It makes for an easy play on words: One Nation Conservatism. However, in this case, the noun is more relevant than the prefix for indeed, Disraeli's One Nation was social. So was Baldwin's or the One Nation established in the 1950 pamphlet. One Nation Conservatism is fundamentally a way of considering society and the related issues, including the UK's place in Europe. Boris Johnson's “infrastructure-friendly" One Nation Conservatism is not One Nation Conservatism.

Yet, whatever the focus of One Nation Conservatism, however, there is one common triggering cause for its sudden appeal. That is the impression that national divisions are forming and that the said divisions are potentially dangerous for the Conservative Party and its electoral future. Can we deduce from this that One Nation Conservatism is often only circumstantial, i.e. a pragmatic device to win elections in an ever-changing world?

Coming back to the origin of One Nation Conservatism, that is Disraeli's declaration in 1872: "Gentlemen, The Tory Party, unless it is a national party, is nothing, It is not a confederacy of nobles, it is not a democratic multitude; it is a party formed of all the numerous classes in the realm - classes alike and equal before the law, but whose different conditions and different aims gives vigour and variety to our national life" ${ }^{26}$, it is obvious that he was aware, with the first extension of the franchise to the working class in 1867 (and, inevitably, more to come), that the party had to find a way to appeal to these new voters that represented the majority of the British population. His approach was pragmatic. One Nation was, to a certain extent, a way for the party of manufacturing the consent of voters who were not regarded as the natural voters of the Conservative Party. Hence the notion that to foster divisions, whether territorial (opposing the rich south to the 
poor north, losing Scotland) or social (a party representing social classes rather than the whole nation), could not be beneficial if the party wanted to appeal to the largest number. One Nation was a circumstantial response to the perception that the nation was divided, one way or other.

Admittedly, the One Nation rhetoric is never so strong as when divisions have to be overcome in order for voters to be lured into voting for the party that is presented as a broad church rather than the party of the privileged few or of some vested interests. This was certainly one of the analyses made to explain why the party was kept in the political desert for thirteen years after John Major's defeat in 1997. Theresa May's "nasty party" was one that divided society, sexes, classes, ethnic groups. It explains why David Cameron insisted on presenting the Conservative Party as socially compassionate to appeal to the centre ground and blue-colour workers supposedly lost because of the divisive policies of the Thatcher era. It is also to foster social harmony that he insisted on his Conservatism being modern, to appeal to the sexual and ethnic minorities. And although singing from another hymn sheet, this is one of the reasons why some MPs resurrected the One Nation spirit with the One Nation Caucus in March 2019. Their objective was also to bridge divisions by appealing to the voters who were scared of the factious and divisive rhetoric of Jacob Rees-Mogg and his right-wing, antiEurope, European Research Group.

In fact, the pro-European stance of the One Nation Group is another, albeit quite controversial, aspect of One Nation Conservatism that we have not mentioned yet. The One Nation Group, since its formation in 1950, has tended to be dominated by proEuropean Conservatives. However, the presence of members who would not accord comfortably with this assumption, demonstrates the same unease regarding Europe as that which is felt by the wider party. This issue has notoriously divided the party since 1973 and the prevailing message of the One Nation Group has therefore tended to depend on who was delivering it rather than on it being the result of a consensus between members over the issue. However, from Heath to Cameron, the so-called One Nation Conservative Prime Ministers - on account of them being actual members of the group - have been pro-European. Admittedly, this justifies the use of the One Nation prefix for the One Nation Caucus formed in 2019. Conversely, it does not do so for Boris Johnson. Obviously, when Johnson launched his own One Nation appeal, Brexit was what the majority wanted. Within this majority, there was an important proportion of voters with a working-class background who had traditionally voted for the labour Party. Johnson's One Nation appeal was maybe his attempt to persuade these voters that he shared the same concern about poverty in Britain, a concern that would be more strongly associated with One Nation than with right-wing neoliberal Conservatism. To quote but one study amongst others, $65 \%$ of the respondents to a survey carried out by NatCen for their 2019 Report held the view that there was "quite a lot" of poverty in Britain and that "the poverty level ha[d] been rising [since 2006] and [would] continue to rise in the future" ${ }^{57}$. Of these, $73 \%$ were Labour supporters compared with $51 \%$ of Conservative supporters. By presenting himself as a One Nation Conservative who would "get Brexit done", Johnson was attempting to put the party in a win-win situation. Was he thus demonstrating the flexibility of a notion that can serve many different purposes or that One Nation Conservatism, at least his, is merely: "a code term for trying to make the party electable and to keep the party electable" 58 . 


\section{Conclusion}

In all periods of its existence, the One Nation group has displayed attributes distinguishing it from the mainstream of the Conservative Party, over the issue of Britain's membership of the European Union or because of its sometimes more interventionist economic and social vision than that of Conservative Governments. For these reasons, One Nation Conservatisms may not have always been as popular as all that amongst grassroots Conservative voters. They certainly were not when Margaret Thatcher was attempting to reform the Conservative Party and it became an even less popular brand during the whole of the period of the so-called Maastricht rebellion when John Major was seeking the support of his party to pass the Maastricht Bill. And indeed, recently, One Nation Conservatism has been torn over the issue of Britain's continued membership of the European Union, thus merely reflecting a wider issue within the Conservative Party. The fact that the prefix could be used by both the proEuropean MPs of the One Nation Caucus and the Brexiter PM, Boris Johnson, is indicative of these tensions. Because of this association with Europe, Johnson's decision to use the One Nation label was therefore a risk. It was also a risk because of the association between One Nation and state intervention. Indeed, on 27 December 2019, Paul Goodman, editor of the centre-right political blog ConservativeHome ${ }^{59}$ carried out a survey amongst party activists asking them "Which of the following statement is closest to your view?". The majority, i.e. 59.93\% agreed with: "I believe that there is a lot to be said for a One Nation appeal, but I am distrustful of interventionist politics, and am nervous of this government straying too far from Conservative principles", another $5.5 \%$ thought that there was "little to be said for a One Nation appeal, dislike[d] interventionist politics and believe[d] that this government is already straying too far from Conservative principles" and $2.33 \%$ opposed the "One Nation ideal, believe[d] that government should rarely intervene in the economy, and think that if it does, Conservative gains in the recent election will vanish". $32.25 \%$ "support the One Nation idea, believe that government should frequently intervene in the economy, and think that if it doesn't the Conservative gains in this month's election will vanish". When the One Nation tradition was born, the grassroots Conservative members did not have much influence on the way the leadership of the party was determined. They have had since 1998 and the message of the leader of the party is inevitably congruent with their expectations as well as with those of the wider public, i.e. citizens who will usually vote for the party but are not members as well as the ever-important swing voters. It was a risk indeed, but one that paid because of the nature of what One Nation Conservatism has become, maybe even what it has always been.

And indeed, One Nation Conservatism is at best a flexible notion that is defined by whoever dominates the debate of ideas at the time it is appealed to or at worst an easy label that is conveniently used to make the Conservative Party seem more attractive. In fact, it is very unlikely that the mainstream has a strong notion of what One Nation Conservatism really is, especially as the majority are now more likely to be Thatcher's children than Heath's. The younger generations who grew up during and after Thatcher's premierships have rarely heard the expression after all. It would be interesting to see if such papers as The Sun, for example, sometimes use the expression to discuss and analyse Conservative policies. We have also demonstrated in this paper that it was revived by Cameron only recently and even so, the adjectives compassionate and progressive were systematically preferred to the prefix One Nation itself. And it 
may be that for the majority, One Nation is just a vague notion that is appealing only because of its positive undertones of unity and "being all in it together". It is very likely to be the reason why Boris Johnson used the label at a time when Britain seemed more divided than ever, because of Brexit and of the tensions it was creating both between English people and between England and its British neighbours. The ongoing Coronavirus Crisis has exposed many of these divisions whilst at the same time contributing to restore the spirit of solidarity that characterised the nation after another major crisis, the comparison now being made with World War Two (see the Coronavirus Speech by Queen Elizabeth II on Sunday 5 April 2020). It would be interesting to see if the One Nation tune will still be played once the crisis has abated and the country is having to deal with its consequences.

Raphaële Espiet-Kilty est Maîtresse de Conférences à l'Université Clermont Auvergne (UCA). Spécialiste de civilisation britannique contemporaine et d'histoire politique, elle travaille sur le Parti conservateur, notamment sur les politiques sociales des gouvernements conservateurs et leur impact sur la société civile. Auteure d'articles récents consacrés à Cameron et May, elle a tenté de démontrer que les politiques incitatives, les encouragements et autres mains tendues vers la société civile, n'ont pas suffi à l'aider à " réparer " la société que les Conservateurs avaient eux-mêmes qualifiée de «brisée ".

\section{BIBLIOGRAPHY}

The Week, «What is One Nation Conservatism?”, https://www.theweek.co.uk/101705/what-isone-nation-conservatism

Bale, Tim, "Memo to May. Don't forget One Nation, Prime Minister" in Conservatism Home, https://www.conservativehome.com/platform/2016/10/tim-bale-memo-to-may-dont-forgetone-nation-prime-minister.html

Bale, Tim, Five Year Mission, Oxford : Oxford University Press, 2015.

Bale, Tim, The Conservative Party from Thatcher to Cameron, Cambridge : Polity Press, 2010.

Bale, The Conservatives since 1945 : the drivers of party change, Oxford : Oxford University Press, 2012.

DOI : 10.1093/acprof:oso/9780199234370.001.0001

Cameron, David, «A New Politics », The Guardian, 25 May 2009.

Cameron, David, Leadership acceptance speech, 2005, <http://www.britishpoliticalspeech.org/ speech-archive.htm?speech=315>.

Cameron, David, The Age of Austerity, Tory Spring Conference, Cheltenham, 26-27 avril 2009, <http://www.politics.co.uk/comment-analysis/2009/04/27/tory-spring-conference-speeches-infull>.

Cameron, David, The Big Society, 10 November 2009, <http://conservative-

speeches.sayit.mysociety.org/speech/601246>. 
Carr, Richard, One Nation Britain, History, the Progressive Tradition, and Practical Ideas for Today's Politicians, London: Routledge Taylor \& Francis Group, 2014.

Curtice, John, Clery, Elizabeth, Perry, Jane, Philips, Miranda and Nilufer Rahim, Nilufer (eds.), British Social Attitudes 36, 2019 Edition, NatCen Social Research that works for Society, London: The National Centre for Social research, 2019.

Dorey, Peter \& Garnett, Mark, «'The weaker-willed, the craven-hearted': the decline of One Nation Conservatism" in Global Discourse. An Interdisciplinary Journal of Current Affairs and Applied Contemporary Thought, Vol. 5, No 1, London: Routledge Taylor and Francis Group, 2015, pp. 69-91.

Duncan Smith, I., Breakdown Britain. Interim report on the state of the nation, London, Social Justice Policy Group, December 2006.

Espiet-Kilty, R., “Augmentation de la pauvreté en Angleterre depuis 2010 : crise ou idéologie? The increase in poverty in England since 2010 : crisis or ideology?" in Marshall, Catherine and Guy, Stéphane (dir.), Economic Crisis in the United-Kingdom Today : Causes and Consequences, October 2016, <http://journals.openedition.org/rfcb/1060>

Espiet-Kilty, Raphaële, « Cameron and Big Society, May and Shared Society: Same Party, Two Visions ? » in Whitton, Tim (dir.) Theresa May's United-Kingdom, Revue « L'Observatoire de la société britannique », $\mathrm{n}^{\circ} 21$, avril 2018, 20p, http://osb.revues.org.

Goodman, Paul, "The Limits of Support for One Nation. Our Survey" in Conservative Home, https:// www.conservativehome.com/thetorydiary/2019/12/the-limits-of-support-for-one-nation-oursurvey.html

Griffiths, Simon, “What was Progressive in 'Progressive Conservatism'?" in Political Studies Association of the United Kingdom, Vol. 12, Oxford: Oxford Blackwell, 2014, pp. 29-40.

Hickson, Kevin, "Conservatism and the poor: Conservative party attitudes to poverty and inequality since the 1970s" in British Politics, Vol. 4, London: Palgrave Macmillan, 2009, pp. 341-362.

Institute of Fiscal Studies, Joseph Rowntree Foundation, The Guardian, <https:// www.theguardian.com/society/2017/dec/04/uk-government-warned-over-sharp-rise-childrenpensioner-poverty-study>.

Johnson, B., PM statement in Downing Street: 13 December 2019, https://www.gov.uk/ government/speeches/pm-statement-in-downing-street-13-december-2019

Johnson, B., PM statement in Downing Street: 13 December 2019, https://www.gov.uk/ government/speeches/pm-statement-in-downing-street-13-december-2019

May, T., The Conservative chairwoman's speech to the party conference in Bournemouth, 7 October 2002, in The Guardian, <https://www.theguardian.com/politics/2002/oct/07/ conservatives2002.conservatives1>.

May, T., Launch of the Leadership Campaign, 11 July 2016, <http://press.conservatives.com/post/ 147947450370/we-can-make-britain-a-country-that-works-for>.

May, T., Forward Together : The Conservative and Unionist Party Manifesto 2017, < https:// www.conservatives.com/manifesto>.

May, T., The Shared Society Speech : Prime Minister's Speech at the Charity Commission annual meeting, 9 Jan. 2017, <https://www.gov.uk/government/speeches/the-shared-society-primeministers-speech-at-the-charity-commission-annual-meeting>. 
Seawright, David, The British Conservative Party and One Nation Politics, New York: The Continuum Publishing Group Ltd., 2010.

Social Justice Policy Group, Breakdown Britain. Interim report on the state of the nation, London : SJPG, December 2006, <http://www.centreforsocialjustice.org.uk/UserStorage/pdf/ Pdf\%20Exec\%20summaries/Breakdown\%20Britain.pdf >.

Walsha, Robert, "One Nation Group and One Nation Conservatism, 1950-2002" in Contemporary British History, Vol. 17, No 2, London: London F. Cass, 2003, pp. 69-120.

\section{NOTES}

1. It is also commonly referred to as the One Nation Group. However, this creates a problem in this article because the One Nation Group is also the name of the group founded in 1950. For the sake of clarity, I will reserve the term group to describe historic One Nation Conservatism and use the term caucus in reference to the Conservative faction created in 2019 (see footnote 6 for further explanation).

2. Caucus is the term used in the article hereafter referenced. I will use this term rather than that of group which I will reserve to discuss matters pertaining to the One Nation Group formed in 1950. The aim is to easily distinguish between the two. https://www.politicshome.com/news/uk/ political-parties/conservative-party/news/103973/amber-rudds-new-tory-group-bid-block

3. Secretary of State for Work and Pension.

4. Johnson, PM statement 2020.

5. Interview with the Lord Biffen of Tanat, 4 March 1998, pp. 69-120.

6. Benjamin Disraeli quoted in David Seawright, The British Conservative Party and One Nation Politics, (New York, The Continuum Publishing Group Ltd., 2010), p. 5.

7. Tim Bale, "Memo to May. Don't forget One Nation, Prime Minister" in Conservatism Home, https://www.conservativehome.com/platform/2016/10/tim-bale-memo-to-may-dont-forgetone-nation-prime-minister.html

8. Walsha (2003), “One Nation Group”, p. 70.

9. Ibid., p. 71.

10. Quentin Hogg (Lord Hailsham), One Year's Work, London: Hutchinson, 1944, p. 80 quoted in Peter Dorey, Peter \& Mark Garnett, «'The weaker-willed, the craven-hearted': the decline of One Nation Conservatism" in Global Discourse. An Interdisciplinary Journal of Current Affairs and Applied Contemporary Thought, Vol. 5, No 1, (London, Routledge Taylor and Francis Group, 2015), pp. 69-91, pp. 72-73.

11. A reference to the classical liberalism of the Manchester school.

12. Dorey \& Garnett (2015), “The weaker-willed”, pp. 72-73.

13. This was the case with the Industrial Charter: A Statement of Conservative Industrial Policy, a pamphlet published in 1947 just three years before the One Nation Pamphlet.

14. A name worth mentioning on account of him being the intellectual force behind the what we could here present as the Thatcher revolution against One Nation Conservatism.

15. TV interview for BBC1 Panorama on 8 June 1987, http://www.margaretthatcher.org/ document/106647 consulted on 2 March 2020.

16. Seawright (2010), The British Conservative Party and One Nation Politics, pp. 59-64.

17. Robert Walsha gives the example of Ian Gilmour in "One Nation Group and One Nation Conservatism", 2003, p. 100.

18. Dorey and Garnett (2015), “The weaker-willed”, p. 76 and pp.80-81.

19. Tim Bale, The Conservative Party from Thatcher to Cameron, (Cambridge, Polity Press, 2010), p. 136.

Revue Française de Civilisation Britannique, XXV-3 | 2020 
20. Walsha (2003), “One Nation Group”, p. 96.

21. May, Theresa, The Conservative chairwoman's speech to the party conference in Bournemouth, 7 October 2002, The Guardian, https://www.theguardian.com/politics/2002/oct/ 07/conservatives2002.conservatives1 consulted on 4 February 2020.

22. David Cameron, The Big Society, Nov. 10 2009, http://www.conservatives.com/News/Speches/ 2009/11/David_Cameron (this is only one example as this reference can be found in many of Cameron's speeches.

23. Bid.

24. David Cameron, Cameron's Victory Speech after the Tory leadership election result, 2005, http:// news.bbc.co.uk/2/hi/uk_news/politics/4504722.stm consulted on 4 February 2020.

25. For the controversy over the first version and the outcome see https:// conservativehome.blogs.com/torydiary/built_to_last/ consulted on 4 February 2020.

26. The Conservative Party Manifesto, Strong Leadership. A Clear economic plan. A brighter more secure future, 2015, PDF version in http://www.ucrel.lancs.ac.uk 盛 localpdf 娣 Conservatives

27. Cameron, David, Speech to the Conservative Party Conference, 1 October 2008, http:// www.guardian.co.uk/politics/2008/oct/01/davidcameron.toryconference1.

28. Cameron, David, Cameron victory speech, http://news.bbc.co.uk/2/hi/uk_news/politics/ 4504722.stm

29. Expression first coined by Iain Duncan Smith and the object-study of the Think Tank he created and chaired in 2005, i.e. the Centre for Social Justice.

30. And then again from 2015 to 2016.

31. For exemple see, Espiet-Kilty, Raphaële, “Augmentation de la pauvreté en Angleterre depuis 2010 : crise ou idéologie? The increase in poverty in England since 2010: crisis or ideology?" in Marshall, Catherine and Guy, Stéphane (dir.), Economic Crisis in the United-Kingdom Today: Causes and Consequences, octobre 2016, https://rfcb.revues.org/1060 ; https://rfcb.revues.org and Institute of Fiscal Studies, Joseph Rowntree Foundation, The Guardian, https:// www.theguardian.com/society/2017/dec/04/uk-government-warned-over-sharp-rise-childrenpensioner-poverty-study

32. In 2004.

33. In 2005.

34. Formed after the issuing by the CSJ of: "Breakdown Britain" in 2006.

35. May, T., Launch of the Leadership Campaign, 11 July 2016, http://press.conservatives.com/ post/147947450370/we-can-make-britain-a-country-that-works-for

36. Ibid.

37. Ibid.

38. David Cameron once said: "We believe in society. But it's not just the same thing as the state". ????????

39. Cameron, David,

40. Ibid.

41. Or maybe Nick Timothy, her political advisor and speechwriter who was credited (with Ben Gummer) for being responsible for the writing of the Conservative Party's 2017 Manifesto. A selfproclaimed Red Tory, he very recently published Remaking One Nation. The Future of Conservatism (Cambridge, Polity Press, 2020).

42. The manifesto that contained most of the pledges mentioned earlier was shaped by Nick Timothy whose vision we will discuss in the third part.

43. From Vindication of the English Constitution in a Letter to a Noble and Learned Lord (London, 1835).

44. Speech to the Conservative Party Conference in Blackpool, October 1975, https:// www.margaretthatcher.org/document/102777

45. Theresa May's Equality Strategy Speech in November 2010, https://www.gov.uk/ government/speeches/theresa-mays-equality-strategy-speech 
46. https://www.telegraph.co.uk/news/uknews/10480232/Boris-Johnson-Economic-equalitynot-possible.html

47. https://www.gov.uk/government/speeches/boris-johnsons-first-speech-as-primeminister-24-july-2019

48. Ibid.

49. https://www.politicshome.com/news/uk/political-parties/conservative-party/borisjohnson/news/106987/read-full-boris-johnsons

50. https://www.telegraph.co.uk/news/election-2010/7653636/Boris-Johnson-interview-Myadvice-to-David-Cameron-Ive-made-savings-so-can-you.html

51. https://www.conservativehome.com/thetorydiary/2019/12/the-limits-of-support-for-onenation-our-survey.html

52. This was before the onset of the coronavirus pandemic.

53. Conservative Party Manifesto,

54. Initially approved on 23 February 2017, the project proved very controversial mostly because of the escalating cost and, upon succeeding Theresa May, Prime Minister Boris Johnson commissioned a review of the whole project in August 2019.

55. Conservative Manifesto (2019), ibid

56. Benjamin Disraeli quoted in Seawright (2010), The British Conservative Party and One Nation Politics, p.p. 4-5.

57. John Curtice, Elizabeth Clery, Jane Perry, Miranda Philips and Nilufer Rahim (eds.), British Social Attitudes 36, 2019 Edition, NatCen Social Research that works for Society, London: The National Centre for Social research, 2019, p. 141.

58. Interview with the Lord Biffen of Tanat, 4 March 1998 in Walsha (2003), "One Nation Group and One Nation Conservatism", pp. 69-120.

59. Goodman, John (2019), https://www.conservativehome.com/thetorydiary/2019/12/thelimits-of-support-for-one-nation-our-survey.html

\section{ABSTRACTS}

On 13 December 2019, in Downing Street, Prime Minister Boris Johnson announced the formation of what he called a "new One Nation Conservative Government, a people's government". A few months earlier, a dozen Conservatives had formed a One Nation Caucus ${ }^{1}$ in a bid to block candidates who backed no-deal Brexit in the leadership contest due to start upon Theresa May's resignation as Prime Minister. Johnson was supposedly one such candidate and therefore not considered a One Nation Conservative by his colleagues who continued by issuing a manifesto that took aim at him. That there should be different factions within the Conservative Party is not surprising. However, what is One Nation Conservatism if two opposed factions can both claim the label as their own? The aim of this paper is to examine and compare the recent appeals to One Nation Conservatism, with a focus on the Conservative Party since David Cameron, in order to try and establish where to position the new Conservative PM in the long One Nation tradition. The approach will be a historical one with, in the first part, a presentation of One Nation Conservatism from its birth onwards that will enable us, in the second part, to assess whether it is possible to position Johnson in this intellectual tradition. The second part will examine Johnson's One Nation Conservatism in relation to his two direct predecessors'. The third part will consider the more 
loaded charge that One Nation "in a way has just become a code term for trying to make the party electable and to keep the party electable" to quote Lord Biffen, himself a leading One Nation Conservative. If this is so, then is it possible to argue that Boris Johnson is merely an opportunist One Nation Conservative?

Le 13 décembre, à Downing Street, Boris Johnson annonça la formation d'un: «nouveau Gouvernement conservateur One Nation, un gouvernement du peuple ». Quelques mois plus tôt, une douzaine de conservateurs avaient créé un caucus One Nation pour tenter d'empêcher les candidats favorables à un Brexit dur de l'emporter lors des élections à la tête du parti, élections qui devaient débuter le jour de la démission de Theresa May, le premier ministre en poste. Boris Johnson, censément un Brexiter dur, n'était donc pas considéré comme un conservateur One Nation par ses collègues. D'ailleurs, le manifeste qu'ils publièrent ne l'épargnait pas. Qu'il y ait diverses factions au sein du Parti conservateur n'est pas surprenant. Par contre, qu'est-ce que le conservatisme One Nation si deux factions opposées l'une à l'autre peuvent toutes deux s'en réclamer ? L'objectif de ce papier est d'analyser et de comparer les différents courants se réclamant du conservatisme One Nation aujourd'hui, et plus particulièrement depuis David Cameron, afin de positionner le nouveau premier ministre conservateur dans la longue histoire intellectuelle dudit courant. L'approche sera historique avec une première partie retraçant l'histoire du conservatisme One Nation. Cet historique nous permettra de voir s'il est possible d'associer Boris Johnson au courant. La seconde partie affinera l'étude en comparant Boris Johnson à ses deux prédécesseurs directs. Finalement, nous évoquerons le point du vue de de Lord Biffen, lui-même chef de file historique du courant One Nation, qui décrit celui-ci comme une simple «étiquette servant au parti à gagner des élections et à rester attrayant ». Est-il alors possible d'arguer que le One Nation de Boris Johnson est un One Nation de circonstance?

\section{INDEX}

Mots-clés: One Nation, conservatisme, Boris Johnson

Keywords: One Nation conservatism, Boris Johnson

\section{AUTHOR}

\section{RAPHAELE ESPIET KILTY}

Université Clermont Auvergne 